\title{
Cocoa combined with palm wine in Côte d'Ivoire: An unexpected resilience
}

François RuF

Cirad

Département Environnement

et sociétés

UMR Innovation

TA C-85

73 rue Jean-François Breton

34398 Montpellier Cedex 5

France

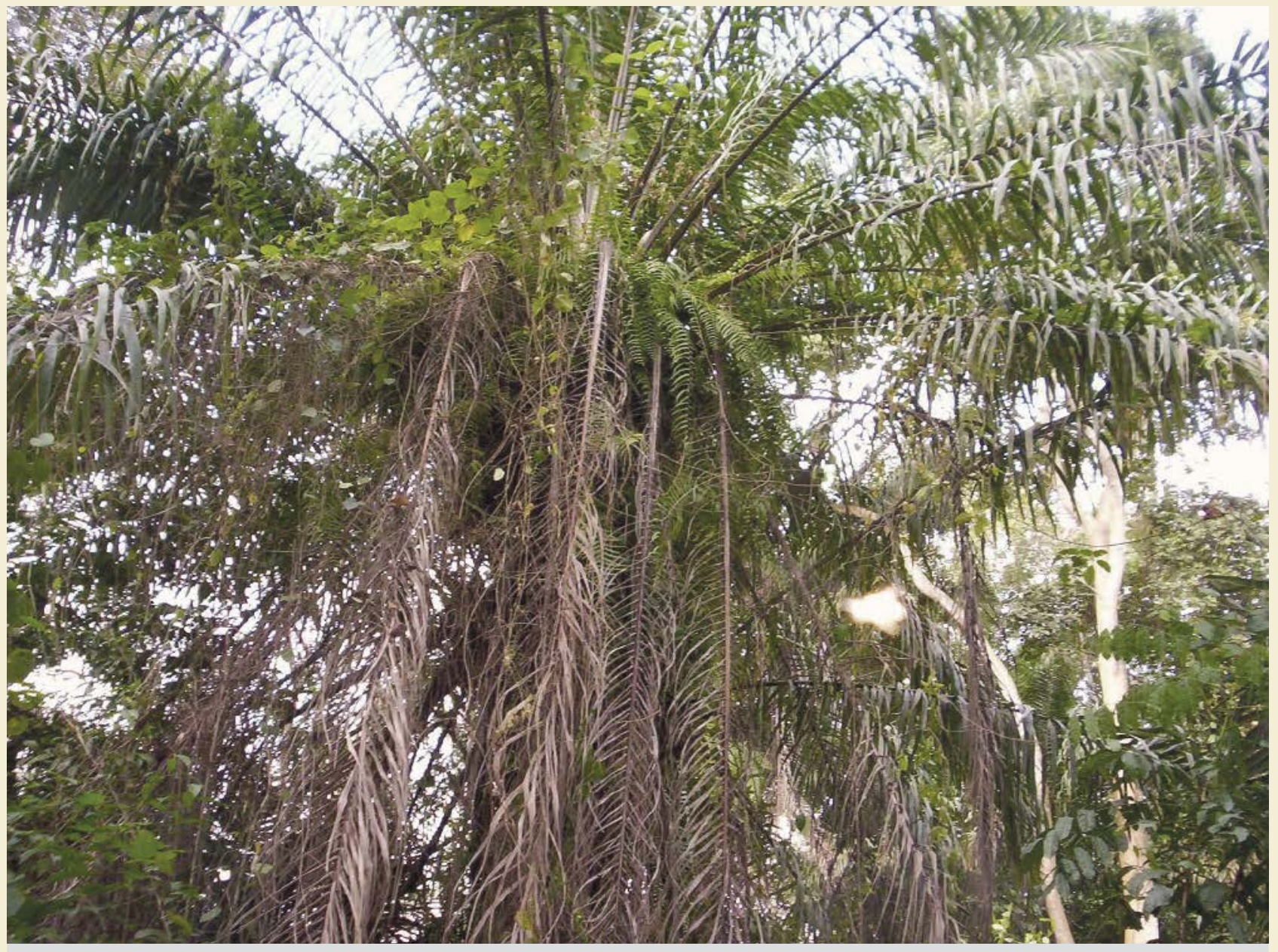

Photo 1.

Palm tree.

Photo F. Ruf. 


\section{RÉSUMÉ}

\section{CACAO ET VIN DE PALME EN CÔTE D'IVOIRE : UN FACTEUR DE RÉSILIENCE INATTENDU}

La vigueur du palmier à huile sauvage est telle que cette espèce fait presque figure de " mauvaise herbe » dans les plantations de cacao négligées ou abandonnées. Pourtant, le palmier à huile en Afrique de l'Ouest est très apprécié pour la production de vin de palme, et pourrait permettre aux agriculteurs de compléter et diversifier leurs revenus. Dans le centre-ouest de la Côte d'Ivoire, la reprise du palmier à huile sauvage dans les anciennes plantations de cacao a joué un rôle important dans les années 1990, lorsque les paysans se sont trouvés confrontés à l'effondrement des cours du cacao et à des conflits d'héritage, qui ont entraîné l'abandon de nombreuses plantations de cacao où la densité des palmiers à huile a rapidement augmenté. L'abattage des palmiers permettait de produire du vin de palme pour la vente et l'autoconsommation, générant ainsi des revenus, réduisant les risques et créant de l'emploi et de nouveaux dispositifs intergénérationnels et institutionnels. Dans les régions tropicales humides, les plantes d'importance économique locale comme les palmiers à huile peuvent accroître la résilience des agriculteurs aux chocs extérieurs. Au lieu de concentrer les efforts sur la seule intensification, il conviendrait d'évaluer les cultures de relais et leur impact sur la résilience de l'arboriculture sur l'ensemble du cycle de vie des exploitations.

Mots-clés : services environnementaux, portefeuille arboricole, cycle de vie familial, diversification, cultures de relais, renouvellement intergénérationnel, Côte d'Ivoire.

\section{ABSTRACT}

\section{COCOA COMBINED WITH PALM WINE IN CÔTE D'IVOIRE. AN UNEXPECTED RESILIENCE}

Wild oil palm growth is so vigorous that it may be almost considered as a "weed" in neglected and abandoned cocoa farms. However, West-African oil palm is valued for its production of palm wine, and may provide additional revenues and income diversification. In the central-western region of Côte d'Ivoire, wild oil palm from old cocoa farms played a major role in the 1990s, when farmers simultaneously faced the impact of the collapse of cocoa prices and of conflictual inheritance processes leading to the temporary abandon of many cocoa farms where the density of oil palm then increased rapidly. Palm wine was tapped by cutting down palm trees. It generated self-consumption, revenues, risk reduction, employment and inter-generational and institutional arrangements. In the Humid Tropics, plant species of local economic importance such as wild oil palm can help increase the resilience of farmers to external shocks. Rather than trying to look only for an intensification trend, it is also relevant to evaluate the relay cropping and its resilience of a tree-crop farm over its full life-cycle.

Keywords: environmental services, tree crop portfolio, family life cycle, diversification, relay cropping, generation change, Côte d'Ivoire.

\section{RESUMEN}

\section{CACAO Y VINO DE PALMA EN COSTA DE MARFIL: UN FACTOR DE RESILIENCIA INESPERADO}

La palma aceitera silvestre posee tanto vigor que casi se la podría considerar como una "maleza" en cacaotales descuidados o abandonados. Sin embargo, la palma aceitera es muy apreciada en África occidental para producir vino de palma, y podría permitir a los agricultores completar y diversificar sus ingresos. En el centrooeste de Costa de Marfil, la recuperación de la palma aceitera silvestre en los viejos cacaotales desempeñó un importante papel en la década de los 90, cuando los campesinos tuvieron que afrontar el hundimiento de los precios del cacao y conflictos de herencia que llevaron al abandono temporal de muchas plantaciones de cacao, provocando un rápido aumento de la densidad de palma aceitera. Mediante la tala de las palmas se obtuvo vino para la venta y el autoconsumo. Esto generó ingresos, redujo riesgos, creó empleo y permitió establecer mecanismos intergeneracionales e institucionales. En las zonas tropicales húmedas, las plantas de importancia económica local como la palma aceitera pueden incrementar la capacidad de resiliencia de los agricultores a los choques externos. En lugar de concentrar todos los esfuerzos en la intensificación, sería también conveniente evaluar los cultivos de relevo y su impacto en la resiliencia de los cultivos arbóreos durante todo su ciclo de vida.

Palabras clave: servicios ambientales, portafolio de cultivos arbóreos, ciclo de vida familiar, diversificación, cultivos de relevo, renovación intergeneracional, Costa de Marfil. 


\section{Introduction}

In the late 1980 s/mid-1990s, cocoa farmers in Côte d'Ivoire faced a multiple crisis. First of all, it was a period of economic hardship, including the collapse of the cocoa price in $1988 / 89$ and the $50 \%$ devaluation of the CFA Franc in 1994, doubling the price of inputs and imported goods. It was followed by a revival of the nominal cocoa price in 1996/97 but many farmers were impoverished. Secondly, many regions such as the centre-west faced the first signs of cocoa trees ageing. Thirdly, as a consequence, migrant workers were reluctant to work in old cocoa regions. Fourthly, after massive immigration of young men in the Ivorian forest zone from drier parts of Côte d'Ivoire and neighbouring countries in the late 1960s, the mid-1990s saw a revival of conflicts between migrants and autochthons, often manipulated and enhanced by politician games after the death of the President Houphouët-Boigny. Fifthly, this period was also marked by a beginning of a generational change among the cocoa farmers. Such periods of inter-generational transfer of farm ownership are times of social tension, triggering intra-family conflicts of succession. For all these reasons, in these cocoa established regions, production started to decline and farmers were getting poorer (Léonard and Oswald, 1996; Ruf 1991, 1994).

In these cocoa farms, wild oil palm can be considered as a sub-spontaneous weed on cocoa farms. A dense population of oil palm can be seen as a testimony of neglect and abandonment of the cocoa farm. As a divine surprise, it will reveal that this dense oil palm population helped to cope with the crisis in 1995/96. What was the role of oil palm? How to explain this apparent paradox? Is it one showcase of benefits brought by agroforestry systems?

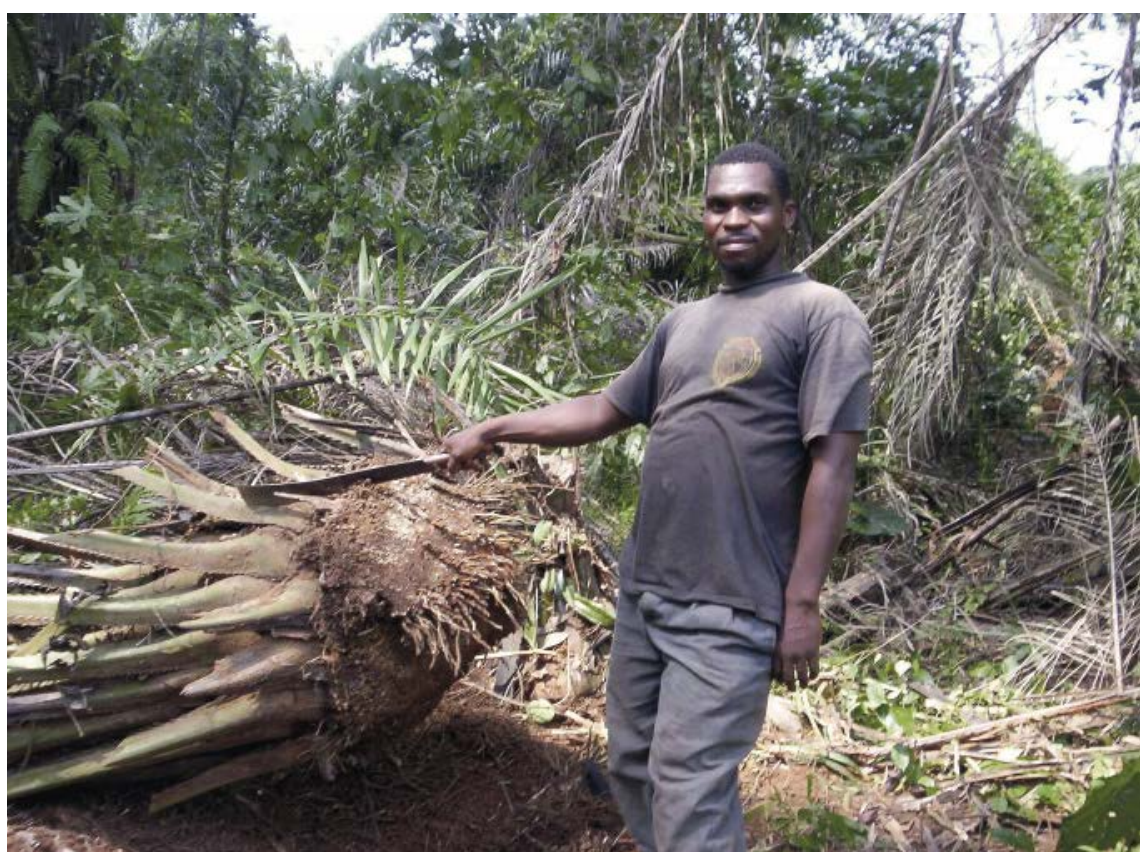

Photo 2.

Palm tree cut down before palm wine extraction.

Photo F. Ruf.
From an ecological perspective, agroforestry systems should provide some environmental services to the farmers, such as pest reduction, soil fertility conservation or atmospheric nitrogen fixation, thereby reducing expenses for agrochemical inputs. Such ecological services of cocoa agroforestry have often been difficult to demonstrate. Smallholders are influenced in their agricultural management decisions by the negative effects of shade trees, such as yield reduction and increased disease pressure such as black pod, which are more obvious than the more subtle and longer-term beneficial effects of shade trees on pest dynamics and soil fertility (Schroth et al., 2000; Ruf et al., 2006; Feintrenie et al., 2010).

From an economic perspective, a cocoa agroforestry system (CAFS) deserves its name when the other species associated to cocoa make a meaningful contribution to the economic sustainability of the system through product diversification, thereby reducing production and market risks and stabilizing revenues over time (Basterrechea et al., 2011).

From a social perspective, a CAFS may facilitate some redistribution of revenues between fathers and sons (Dupraz and Morisson, 2013). Palm wine is recognised as a key element of social life (Champaud, 1970).

In this cocoa/oil palm story, did oil palm help farmers to reduce risks of price volatility related to sudden, drastic changes in the cocoa world market and national policies? As a component of an agroforestry system, did oil palm deliver ecological services to the farmers? What was the place of this cocoa/oil palm agroforestry in plantation and family life cycles? How did it impact and is it impacted by institutional arrangements in cocoa regions?

The main objective is here to describe and explore this story in the mid-1990s in order to answer these questions and explain the apparent paradox, and then compare with the evolution in the late 2000s.

Since a new devaluation of the CFA cannot be excluded within the present decade and since cocoa farmers are again under various pressures, including land conflicts and intergenerational transfers, understanding the way farmers have coped with the crisis of the mid-1990s and evolve in the late 2000s remains relevant not only from an academic perspective. This is a view towards understanding mechanisms of resilience to future crises in the Ivorian smallholder cocoa economy.

This is also a showcase to argue that rather than trying to understand change in terms of spatial organisation at year "y", it is clearly more interesting to analyse smallholder agroforestry strategies over 25 to 30 years, a generation time. 


\section{Methods and location}

Two palm genera are used for wine making in the forest zone of the Côte d'Ivoire; Raphia spp. is the less important one, while the wild oil palm, Elaeis guineensis, is the dominant species for wine tapping which involves cutting down the trees. Wild oil palm trees only start bearing fruit when they are 6-7 years old and are usually cut down for wine when they reach 10-15 years. One reason is that older oil palm may generate too much shade to cocoa. Another one is that old high trees make harvesting of bunches difficult.

In 1996, in order to evaluate the importance of oil palm in cocoa farms, and to understand how farmers manage this resource, cocoa, oil palm, and other trees were inventoried in 88 quadrats of $15 \mathrm{~m} \times 15 \mathrm{~m}$ chosen randomly in cocoa farms belonging to 40 planters in 5 villages of the Ouragahio district in the west-central region of Côte d'Ivoire.

In 1997, in order to assess the role of palm wine in the household economy, a survey was conducted to estimate wine production from wild oil palm among 73 households in the same villages. The households were selected because they exploited palm trees. A questionnaire was applied to the most visible palm-wine extractors, who were either the plantation owners or a family member, worker, or neighbour.

In 2008, in order to identify how farmers evolved in their oil palm/cocoa strategies, cocoa, oil palm, and other trees were again inventoried in 80 quadrats of $30 \mathrm{~m} \times 30 \mathrm{~m}$ chosen randomly in cocoa farms belonging to around 40 planters. These observations were not carried out systematically in the same farms and villages, but it has been maintained the same proportion of autochthons and migrants and comparable sub-samples of 50 mature farms at the average age of 24 years.

This district represents a typical "piece" of the Côte d'Ivoire "cocoa and migration" story. In the early 1960s, the migrant population was so limited and discrete that it remained unmentioned in a large study of the West-central region that lasted for one full year. The population was considered autochthon (mostly Bété) and its density was around 15 inhabitants per $\mathrm{km}^{2}$, growing mostly coffee. Cocoa was still marginal. Mostly through migration, this coffee region was turned into a cocoa region. It reached an estimated density of 80 inhabitants $/ \mathrm{km}^{2}$ in the late $2000 \mathrm{~s}$. This Ouragahio district in the Western-Central region is thus particularly suited to evaluating cocoa/oil palm agroforestry practices in an old cocoa region.

\section{Results and discussion}

As a first step, it is needed to understand who are the cocoa farmers in the mid-1990s, and what is the place of oil palm in their farms.

\section{Who are the cocoa/farmers? What is the place of oil palm?}

All the information obtained in 1996 in the 88 quadrats show that almost all cocoa farmers had oil palm in their farms. Only $9 \%$ of the quadrats do not include oil palm. The global average was 365 oil palm trees per hectare, associated to 1,150 cocoa trees per hectare.

The 365 oil palm were composed of 311 below 6 years old, 50 between 6 and 10, and only 4 above 10 . This age structure demonstrates that most oil palm trees were actually felt down early, at 10 years old. This was a first indication of the relative necessity for farmers to exploit the palm wine as soon as possible to compensate the low cocoa revenues.

There was no significant difference in cocoa and oil palm density between the different three main ethnic groups, the Bété (autochthons) and the Baoulé and Burkinabè, the most important migrant communities. However, among the Burkinabè, a sub-group was starting to rehabilitate the old farms, by applying a strategy of underplanting: they planted cocoa seeds or seedlings below the old cocoa trees. They were the most advanced in replanting, provisionally pushing the cocoa density to 1,800 trees and at the same time totally eliminating the oil palm older than 10 , and reducing the density of oil palm younger than 10 years below an average 200 . This was a first confirmation that a very high density of wild oil palm was a sign of neglecting the cocoa farm. A process of rehabilitation and better maintenance of the cocoa farms implied to reduce the density of oil palm.

All the information obtained in 1997 in the 73-farmer survey illustrates the dynamics of the family plantation economy in the Western-Central region of Côte d'Ivoire, especially a clear distinction between these three ethnic/geographic origins of cocoa farmers. Behind the ethnic criteria, a pronounced economic differentiation is evident (table I).

Although being the group with the best access to land, autochthonous Bété remained small-scale planters. Until the 1980s, they had mostly been coffee farmers. In the 1990 s, after years of low returns, they turned to cocoa but continued to grow a certain number of coffee trees, which provided around $20 \%$ of their income from tree crops.

Table I.

Mean area, production and revenues of cocoa/coffee farms in Ouragahio District in 1996/1997 with respect to the ethnic origin of heads of households and according to a 73 household survey performed in 1997.

\begin{tabular}{l|c|c|c|c|} 
& $\begin{array}{c}\text { Autochthons (Bété) } \\
\text { Cocoa + Coffee }\end{array}$ & $\begin{array}{c}\text { Migrants (Baoulé) } \\
\text { Cocoa + Coffee }\end{array}$ & $\begin{array}{c}\text { Migrants (Burkinabè) } \\
\text { Cocoa + Coffee }\end{array}$ & $\begin{array}{c}\text { All farmers } \\
\text { Cocoa + Coffee }\end{array}$ \\
\hline Area (ha) & $2.0+0.8$ & $7.9+1.2$ & $2.9+0.9$ & $4.5+1.0$ \\
\hline Production (kg) & $942+182$ & $5036+63$ & $1809+512$ & $2725+226$ \\
\hline Revenues (US\$) & $673+163$ & $3597+56$ & $1292+457$ & $1947+202$ \\
\hline
\end{tabular}


Baoule migrants from Central Côte d'Ivoire, on the other hand, were already fully focused on cocoa and were obtaining relatively high yields after clearing primary forest and dense secondary forests. Coffee contributed little to their overall income. In the 1970s and 1980s, they were the champions in the race for forest clearing and in the 1990s they still had the highest revenues owing to their early occupation of suitable forest land and early option for cocoa.

During this period, Burkinabè migrants were still increasing in number through new arrivals and were also in the process of switching from a life as share croppers and labourers of the autochthons to becoming planters themselves. Since they initially had less access to forest land than the politically better connected internal (Baoulé) migrants, they had to plant coffee on degraded fallows where cocoa would not grow well. Although cocoa was their preferred crop, they thus contributed to a large extent to the survival of the Ivorian coffee sector. Although much more successful as planters than the autochthons (Bété), Burkinabè migrants had to nourish a strong social and economic relationship with the autochthons controlling land access. Even though the migrants had formally "bought" their land, each migrant usually gave a small amount of money or a gift at least once per year to his autochthon "tutor" from whom he had obtained the land (Chauveau, 2006; Chauveau and Colin, 2010). As foreigners, Burkinabè had to be more attentive to this non-written rule.

The Burkinabè who are mostly Muslim neither consume much palm wine nor tap the trees themselves but they can sell the palm tree to individuals.

\section{Economic potential and limits of the "cocoa-wild oil palm" agroforestry system}

Self-consumption of palm wine was high and played a major nutritional role according to many farmers claiming that palm wine provided strength and energy. It also met family and social needs and clearly played a major role in festivities, including funerals. This is already a first advantage of oil palm intercropping. When cocoa revenues are low, self-consumption of farm products is a solid trump for the household.
The average revenue drawn from sales of palm wine is only US\$69. However, if self-consumption in the economic evaluation is fully integrated, indicators such as the estimated potential gross revenue (US\$196 per farmer per year in 1997) and the returns per day of labour (US\$3.6 for palm wine tapping versus an average of US $\$ 1.8$ per day of paid labour on a cocoa farm) were relatively attractive. These values may overestimate the true returns to palm wine tapping because at the beginning and at the end of a one-month cycle of palm wine extraction, part of the palm wine is neither saleable nor sold but is kept for self-consumption. However, an estimated $64 \%$ of self-consumption of the wine harvest also is of significant economic and social interest (table II).

All social and economic roles inherent in self-consumption are reinforced by the commercial component, since the domestic market of each village is the village itself plus neighbouring villages. The shifting "banguidromes" (the places where palm trees are cut down and where a large proportion of the palm wine - locally called "bangui" according to its Diula name - is consumed and sold) play the role of "bars" where men meet after a work day in the field. The peak of cocoa harvesting and pod breaking periods, from November to January, is also the period of peak demand for palm wine, although demand is high even during the lean months of cocoa.

Another advantage of palm wine is the daily return it provides. A group of 5-20 palm trees represents a 3-week revenue cycle. This can be renewed by cutting down another group of palm trees if the planter has any left. In the mid1990 s, each year, around 10 palm trees per hectare were reaching the age of 10-12 years old.

In 1997, among the 73 farmers surveyed, we did not identify any of them distilling palm wine to produce a strong alcohol called "koutoukou", which can be easily stored, transported and sold to city dwellers. This can be a way to increase financial returns. Among more pragmatic reasons of occasional under-valuation of the palm wine in migrant farms, one cannot exclude the temptation for young men who got a shareholder contract with old cocoa farmers, often their fathers or uncles, to sell bangui discretely on the side.

Table II.

Estimated revenues of palm wine according to a 73 household survey performed in 1997.

\begin{tabular}{l|c}
\hline & $\begin{array}{c}\text { Estimated potential gross } \\
\text { income from palm wine pe } \\
\text { farmer per year (a) (in USS) }\end{array}$ \\
\hline Autochthonous Bété & 149 \\
\hline Baoulé Migrants & 253 \\
\hline Burkinabè Migrants & 57 \\
\hline Total & 196
\end{tabular}

Estimated actual income from palm wine per farmer per year (b) (in US\$)

\section{Percentage of palm wine sold $b$ / a}

Percentage income from palm wine compared to cocoa and coffee (a) (b) Including self-consumption

\begin{tabular}{|l|r|r|r|r|r|}
\hline Autochthonous Bété & 149 & 70 & $47 \%$ & $8 \%$ & $18 \%$ \\
\hline Baoulé Migrants & 253 & 83 & $33 \%$ & $2 \%$ & $7 \%$ \\
\hline Burkinabè Migrants & 57 & 8 & $14 \%$ & $0.5 \%$ & $3 \%$ \\
\hline Total & 196 & 69 & $36 \%$ & $3 \%$ & $9 \%$ \\
\hline
\end{tabular}


The apparent small percentage of declared commercial revenues can be seen as a limit of this cocoa/oil palm agroforestry system. Although palm wine tapping increases the income of some small autochthon planters by $8 \%$ on average, the contribution of palm wine to migrants' incomes looks rather marginal, between 0.5 and $2 \%$ (table II). However, if we include self-consumed palm-wine in revenues, these percentages respectively jump to $18 \%$ and between 3 and $7 \%$ (table II). Eventually, in 1997, palm wine sales and self-consumption were similar to coffee revenues. If the likely 'hidden' returns and the other economic functions of oil palm, such as seeds and palm oil are added, these wild oil palm trees associated to cocoa become more important. Palm oil produced by these wild palm trees is usually consumed, not sold, except by some Burkinabè women.

The relatively low monetary revenue from palm wine could in part be explained by the large size of the oil palm population in the cocoa farms at this period, which may have led to an oversupply of palm wine and kept its prices relatively low.

However, these apparent limited monetary revenues at the household level incite to look for other functions of the "cocoa-oil palm agroforestry system", starting with the question of the main beneficiaries within the household.

\section{Palm wine, "ethnic" cycles and change in generation}

After massive cocoa adoption in the early 1970s, many farmers in the central-western region had reached their fifties in the mid-1990s. The turn of the second generation was approaching. The population of palm wine extractors can be used to analyse the "ethnic cocoa cycles".

In 1997, among the autochthon population, the percentage of young farmers who started with an inherited farm was already higher than the percentage of first generation farmers who created their farm from scratch. Baoulé migrants followed with slightly fewer inheritors, but younger sons were waiting for their turn. Finally Burkinabè migrants who had arrived later were still first generation farmers (table III).
Some Baoule palm tappers had purchased the palm trees that they were tapping from Burkinabè farmers. However, this palm wine industry was still very much managed within each ethnic group, even within a family. When wine tapping is under the control of a son or nephew who has no cocoa on his own, the relative importance of palm wine revenues obviously increases. Palm wine may generate a precious and initial, small revenue and possibly saving. Finally, only nine palm wine tappers had neither a cocoa/coffee farm nor a family link with the owner of the farm (table III).

\section{Generation cycles and labour arrangements}

Institutional arrangements adopted by farmers to exploit palm wine are in coherence with the specific economic situation of each ethnic group (table IV). Cocoa farmers are 51 years old on average (St. dev. $=13$ ) while the tappers hired by them through a sharing contract are 33 years old on average (St. dev. $=4.4$ ). The great majority of Baoulé migrant planters used a $50 \%$ share cropping contract specifically for palm tapping which was usually given to a young relative (son, nephew, younger brother) or young people with no family connection. Autochthonous farmers with small cocoa farms and a long tradition of palm wine consumption usually tapped the oil palm themselves as part of their culture. The Burkinabè who are mostly Muslim do not consume much palm wine themselves yet managed the resource for their benefit, either by selling the palm trees to younger individuals, frequently to young Baoule or by inviting their "Bété tutors" from whom they had obtained land 10-25 years previously, to cut down and tap their palm trees free of charge. Although symbolic, this "gift" was at the centre of the complex relationship between tutor and migrant, as an early mechanism of strengthening access to and tenure of cocoa land by paying a "palm wine rent". This can be interpreted as a component of the tutorat relationship.

Table III.

Ethnic origin, age and land ownership status of the palm wine tappers according to a 73 household survey performed in 1997.

\begin{tabular}{|c|c|c|c|c|c|}
\hline & $\begin{array}{l}\text { Planters who had } \\
\text { created their farm }\end{array}$ & $\begin{array}{l}\text { Planters who had } \\
\text { inherited their farm }\end{array}$ & $\begin{array}{l}\text { Planters' sons/ nephews } \\
\text { without own farm }\end{array}$ & $\begin{array}{l}\text { No farm and no family } \\
\text { link with planters }\end{array}$ & All farmers \\
\hline Autochthons (Bété) & 10 & 13 & 0 & 2 & 25 \\
\hline Migrants (Baoulé) & 13 & 10 & 9 & 5 & 37 \\
\hline Migrants (Burkinabè) & 9 & 0 & 0 & 2 & 11 \\
\hline Total & 32 & 23 & 9 & 9 & 73 \\
\hline Average Age & 51.4 & 35.2 & 28.3 & 32.1 & \\
\hline Standard-deviation & 13.2 & 7.3 & 8.7 & 8.5 & \\
\hline
\end{tabular}

Note: farm owners do not necessarily own the farm plot where the oil palm tapping takes place. 


\section{Cocoa and oil palm: at the core of biological and economic cycles}

A preliminary analysis of the evolution of tree populations over time in this region shows opposite trends over time between cocoa tree and oil palm densities, id est the older the cocoa farm, the lower the cocoa density (figure 1) and the higher the palm tree density, mostly young oil palm (figure 2). The relatively poor statistical correlation is explained by the dynamics of the mid-1990s, when many palm trees had already been cut down and cocoa was beginning to be replanted in old cocoa groves. There are also a few cases of migrants dividing a farm plot in two and clearing half of all palm trees (with the objective of maximizing cocoa yield and income) and leaving the other half mixed with palm trees so that they could sell the palm trees or allow their indigenous tutor to exploit them in order to maintain a good relationship.

Nevertheless, the trade-off between the declining cocoa density and the increasing density of (mostly young) palm tree density over time is clear and this illustrates two hypothesis raised in the introduction. Firstly, smallholder agroforestry strategies need to be analysed over a long period of time. Secondly, a high density of oil palm is a sign of lower maintenance, neglect and almost abandonment: the older cocoa farms are in this case.

The evidence from the sampling plots is corroborated by the results of questionnaires filled out by households who, at the time, were cutting down and tapping some palm trees. The most part

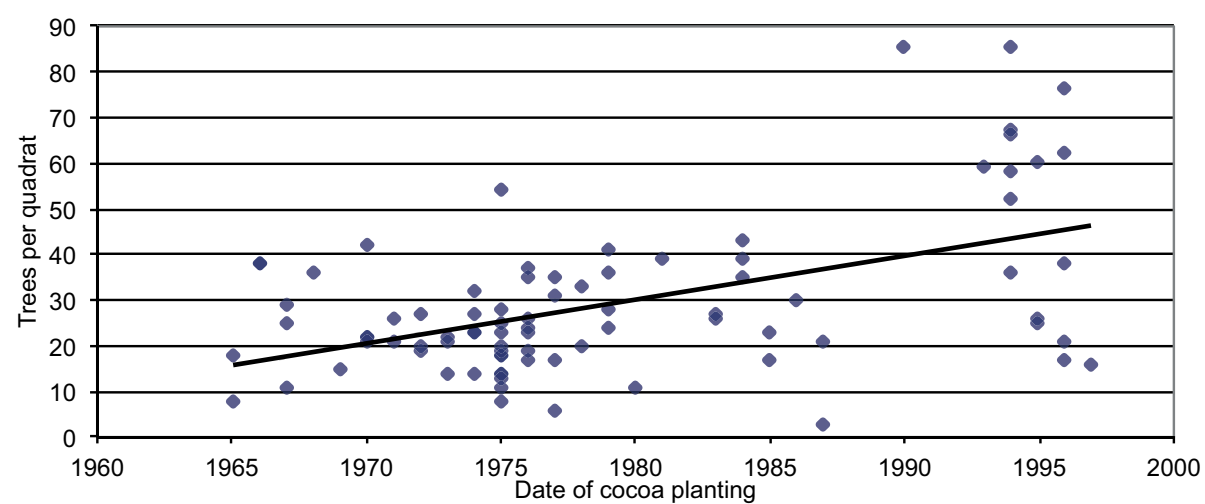

Figure 1.

Date of cocoa planting and density of cocoa trees per quadrat according to a survey of 88 plots performed in 1997 $\left(R^{2}=0.26\right.$ and $\left.P<0.001\right)$.

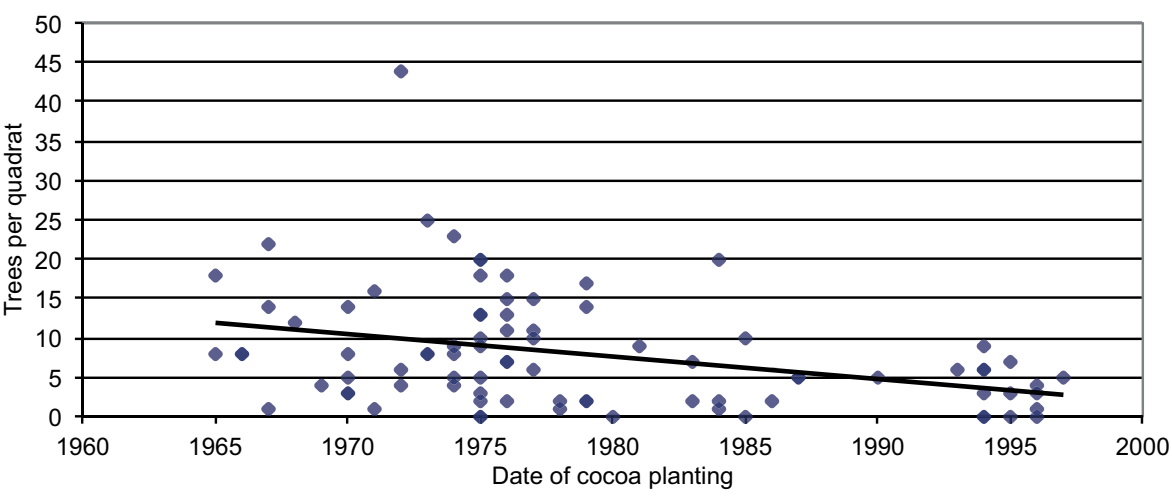

Figure 2.

Date of cocoa planting and palm tree density per quadrat according to a survey of 88 plots performed in 1997 $\left(R^{2}=0.13\right.$ and $\left.P=0.001\right)$.

Table IV.

Types of arrangement made by landowners according to ethnic origin.

\begin{tabular}{|c|c|c|c|c|c|c|}
\hline & $\begin{array}{l}\text { No arrangement: } \\
\text { tapping by } \\
\text { the owner }\end{array}$ & $\begin{array}{l}\text { Tapping by the } \\
\text { owner helped by } \\
\text { a worker or a son }\end{array}$ & $\begin{array}{l}\text { Right to palms } \\
\text { ceded under share } \\
\text { cropping contract }\end{array}$ & $\begin{array}{l}\text { Selling of } \\
\text { palm trees }\end{array}$ & $\begin{array}{l}\text { Giving palm } \\
\text { trees away as } \\
\text { a "present" }\end{array}$ & Total \\
\hline Indigenous (Bété) & 10 & 6 & 2 & 1 & 0 & 19 \\
\hline Migrants (Baoulé) & 3 & 3 & 16 & 1 & 0 & 23 \\
\hline Migrants (Burkinabè) & 1 & 1 & 0 & 3 & 3 & 8 \\
\hline Total & 14 & 10 & 18 & 5 & 3 & 50 \\
\hline
\end{tabular}


of the farms ( $75 \%$; belonging to migrants as well as autochthons) where oil palm trees had been cut down were old cocoa and coffee farms (table V). In the mid-1990s and for autochthonous farmers, old and abandoned coffee farms had become a reservoir of thriving oil palm that progressively replaced the remaining coffee trees. For autochthonous farmers, old coffee and old cocoa farms provided equivalent stocks of oil palm. For migrant groups, old cocoa farms remained by far the best source of mature oil palms that could be exploited for their wine.

Both household surveys and field inventories thus confirmed that wild oil palm was most abundant in old coffee and cocoa farms, which constitute the main source of palm wine and basis for its associated institutional arrangements. This increased density of wild oil palms could be explained in two different ways: it could be a form of "unplanned agroforestry" where the neglect of the old plantations results in increased density of spontaneously regenerating oil palms, which in turn probably contribute to further decline of cocoa yields; or it could be a positive planters' strategy of allowing oil palm to establish and grow on ageing farms in order to obtain alternative revenue at a time when the revenue from the ageing cocoa or coffee declines and farmers become more vulnerable to fluctuating cocoa and coffee prices. The farmers gave their own main reasons for cutting down palm trees for wine tapping (table $\mathrm{VI}$ ).
The combination of the two reasons "source of emergency funding" and "need to liberate the main tree crop" represented more than $70 \%$ of the reasons given by interviewed farmers (table $\mathrm{VI}$ ). These reasons were often given by the same planters, suggesting that the increase in oil palm density in old cocoa farms was in most cases a result of neglect but the farmers were making the best of it. Behind this overall presentation, planters expressed quite complex perceptions of the role of oil palm and palm wine. In $50 \%$ of the "ecological factors" mentioned, farmers insist on the need to "liberate" space (and reduce shade) for cocoa which they rightly considered their main source of income and, to a lesser extent, on the need to get rid of squirrels and snakes which live in palm trees. This argues in favour of unplanned and not-so-desired agroforestry. These reasons were mainly mentioned by migrants, also referring to the problem of the palm trees growing too tall making bunch harvesting too difficult. The higher the density of palm trees in cocoa farms, the more they compete for light. The problem of trees growing too tall over the years thereby increasing difficulties and costs upon harvesting is an almost universal problem related to tree crop ageing and replanting. It is especially true of oil palm, hence the smart option to realize the capital (converting the tree capital into cash) by cutting down the tree and through the palm wine value chain.

\section{Table V.}

Type and number of farms where oil palm was cut down for palm wine according to farmers' statements and ethnic origin of the palm wine tapper as recorded in a 73 household survey performed in 1997.

\begin{tabular}{l|c|c|c|c|c|c|c|c|} 
& Old coffee & $\begin{array}{c}\text { Old cocoa } \\
\text { cocoa/coffee }\end{array}$ & Old mixed & Mature cocoa & $\begin{array}{c}\text { Cocoa } \\
\text { Replanting }\end{array}$ & Fallow & Other & All farms \\
\hline Average date of planting & 1959 & 1971 & 1971 & 1984 & 1990 & & \\
& & & & & & & & \\
\hline $\begin{array}{l}\text { Number of farms } \\
\text { Indigenous (Bété) }\end{array}$ & 8 & 10 & 0 & 2 & 2 & 1 & 2 & 25 \\
\hline Migrants (Baoulé and Burkinabè) & 5 & 27 & 5 & 4 & 4 & 3 & 0 & 48 \\
\hline Total & 13 & 37 & 5 & 6 & 6 & 4 & 2 & 73 \\
\hline
\end{tabular}

Table VI.

Planters' main reasons for cutting down palm trees and tapping palm wine as recorded in a 73 household survey performed in 1997.

\begin{tabular}{|c|c|c|c|c|c|}
\hline & $\begin{array}{l}\text { Ecological factors including } \\
\text { need to reduce shade } \\
\text { and liberate cocoa }\end{array}$ & $\begin{array}{l}\text { Emergency income } \\
\& \text { as alternative } \\
\text { to credit }\end{array}$ & $\begin{array}{c}\text { Access to land } \\
\text { for new planting } \\
\text { of cocoa }\end{array}$ & $\begin{array}{l}\text { Own consumption by family } \\
\text { and friends, and cultivating } \\
\text { social relationships }\end{array}$ & Total \\
\hline Indigenous Bété & $5(12 \%)$ & $28(67 \%)$ & $3(7 \%)$ & $6(14 \%)$ & $42(100 \%)$ \\
\hline Baoulé Migrants & $23(32 \%)$ & $29(40 \%)$ & $12(16 \%)$ & $9(12 \%)$ & $73(100 \%)$ \\
\hline Burkinabè Migrants & $7(39 \%)$ & $4(22 \%)$ & $0(0 \%)$ & $7(39 \%)$ & $18(100 \%)$ \\
\hline Total & $35(26 \%)$ & $61(46 \%)$ & $15(11 \%)$ & $22(17 \%)$ & $133(100 \%$ \\
\hline
\end{tabular}


Among the financial and economic factors (46\%), positive and deliberate strategies represented the vast majority of responses. The most commonly mentioned advantage of oil palm trees was the flexibility to cut them for wine tapping at any time when the farmers needed money (16\%). As palm trees have a ready domestic market, they can provide cash at any time and are consequently looked at almost like a bank account. Cases where such "emergency money" was needed included the children school fees, sickness expenses, funerals (palm wine as a source of cash and, more importantly, for festive consumption), and needs for household equipment, or as an alternative to costly credit in case of food crop failure.

Beyond the simple and clear objective to generate revenues $(12 \%)$, other reasons given by farmers for tapping palm wine included: first, to attract people to participate in pod breaking (6\%); second, to generate income during the months without cocoa revenue ( $5 \%$ ); third, to stabilize income in case of fluctuations of the cocoa price (2\%); and fourth, to fund something specific such as labour and opening of a shop (3\%).

\section{The role of palm wine in pod breaking}

Although only mentioned by $6 \%$ of the interviewed farmers, wild oil palms play an important role in the cocoa economy by providing the essential alcoholic drink for social gathering to break cocoa pods. Especially on large farms owned by Baoulé migrants, pod breaking is usually accomplished collectively with some festive food and drinks provided to attract neighbours and young people. In most cases, this costs more than standard labour contracts but is the only way to bring together enough people to complete pod breaking in half a day. In the 1980s, pod breaking festivities involved abundant supplies of beef, beer and bottled red wine. However, when cocoa prices and revenues collapsed in 1989, there was a general need to reduce these costly festivities. In 1980/81, when the nominal cocoa price to producers was US $\$ 0.5$ per $\mathrm{kg}$, pod breaking costs amounted to US\$1.25 per man-day and US\$0.036/ kg. In 1986 , the cocoa price rose to US\$0.7/ kg. In 1992, the nominal cocoa price was theoretically set at US\$0.35/ $\mathrm{kg}$ but farmers actually got US $\$ 0.30 / \mathrm{kg}$. So there was no longer any money left for beer or wine. The time had come for palm wine. In nominal terms, the costs involved in pod breaking had dropped from US $\$ 0.036 / \mathrm{kg}$ to US $\$ 0.025 / \mathrm{kg}$. Over a period of 11 years, this drop of $25 \%$ in nominal costs represents at least a $70 \%$ reduction in constant currency.

In 1994 , the $50 \%$ devaluation of the CFA franc led to an immediate price increase in tradable and partially imported goods such as beer and wine. The price of one litre of the cheapest beer doubled to reach US\$0.9 while that of one litre of local palm wine remained between US $\$ 0.13$ and US\$0.18, similar to its price before the devaluation. As suggested by one cocoa farmer, " 4 litres of beer cannot match 20 litres or more of palm wine” (20 litres needed for the pod breaking festivities).

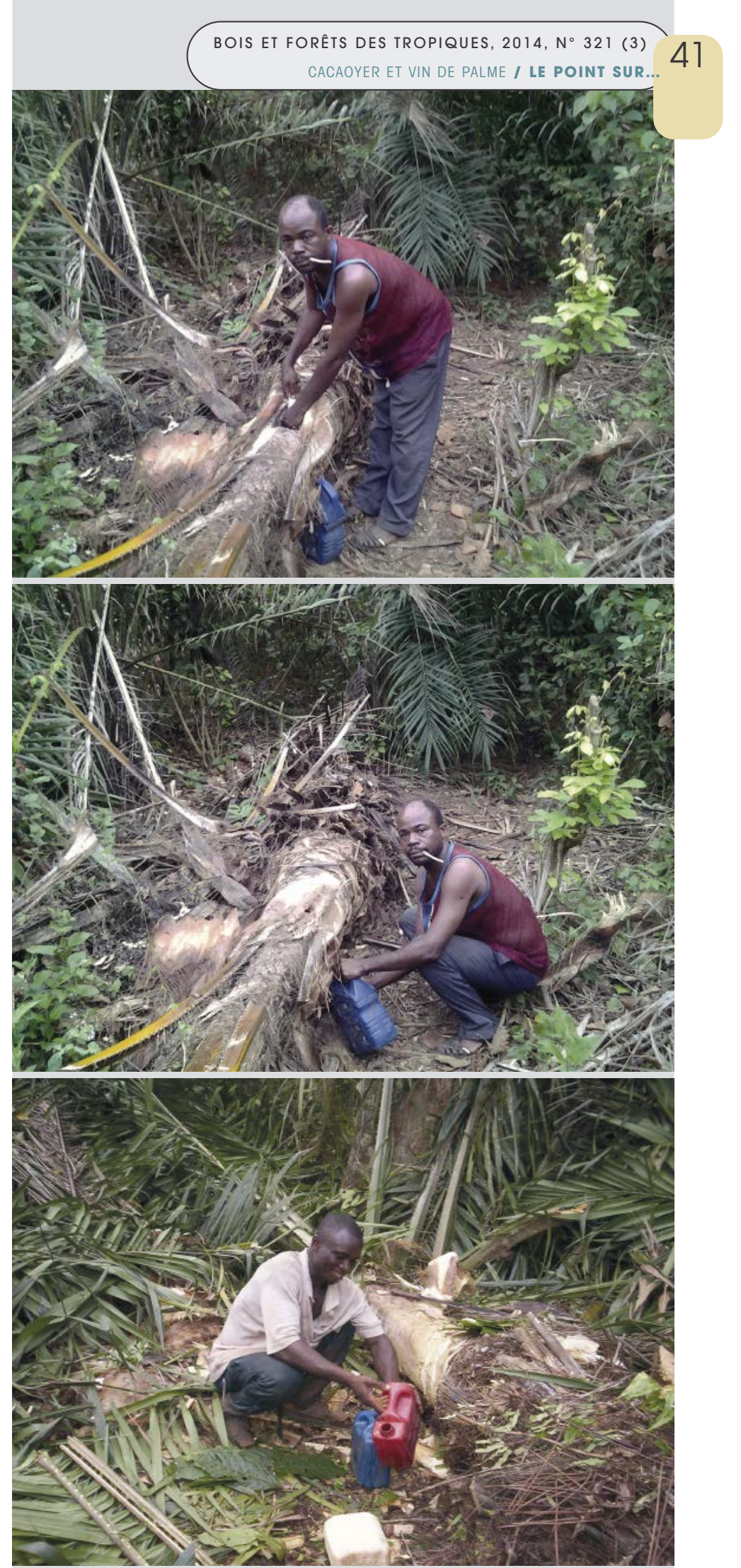

Photo 3.

Palm wine extraction.

Photo F. Ruf. 
Since the early 1990 s and to an even greater extent since 1994, most pod breaking has no longer been washed down with beer and red wine but rather with palm wine. But, when demand for palm wine was skyrocketing, why did the price of this local product remain stable?

As seen above, this is where local history of cocoa and family cycles interact. In the mid-1990s, cocoa farms reached the critical 25-year threshold. Farmers who arrived when they were 25-35 years old were now 50-60 and did not have the same energy. At the same time, they faced an unexpected price collapse that occurred from 1989 to 1994. Many cocoa farms started to be neglected or even abandoned. Among autochthonous farmers, the 1990s were also the decade of a change in generation, which involved abandonment of farms by old farmers, and abandonment due to inheritance conflicts.

In this situation, the ageing of the cocoa farms, reinforced by structural and social causes of farm abandonment, resulted in an enormous stock of oil palm on cocoa and coffee farms which supplied cheap palm wine when it was most needed. This is probably one of the most important aspect of security and resilience brought by this “unplanned” agroforestry system.

\section{From ecological services to the next generation}

Primary forest contains no or very few palm trees, the presence of which is a sign of previous cultivation. The majority of migrant planters confirmed that their forest plot had hardly contained any palm trees when they had cleared it. Usually, palm trees grew "by themselves", thanks to birds and rats that disseminated the seeds. Occasionally the women who prepared meals for the men clearing the forest on the spot would throw away some seeds (table VII).

When oil palm trees grow so well, they may be given the status of "weeds". Planters and their workers often have to cut them at the young stage but as soon as they reduce this weed control, oil palm will come back. When cocoa is planted after a shrub fallow is cleared, oil palm density is already quite high. There is thus a trade-off between the unwanted weed and the potential benefits it can provide such as seeds and later palm wine. However, the spontaneous growth of this species provides capital to generate income. Although or because oil palm has the status of a "weed", it helps to cover and protect the soil.

Oil palm and palm wine may help a second generation of farmers to start their own life as planters and fund the rehabilitation of an inherited cocoa farm. In many cases, the farm had been neglected by the previous ageing planter and/or during the years of inheritance conflict. Among farms exploited for their palm wine, the average acknowledged period of abandonment is 2.8 years for autochthons' households, one year for Baoulé migrants, and three months for Burkinabè (who buy abandoned coffee farms from the autochthonous Bété).

This hypothesis of abandonment is thus demonstrated and explains the huge density of very young palm trees, This "spontaneous" oil palm agroforestry and palm wine thus provided an integral economic link between plantation cycles and family and ethnic cycles, precisely at a difficult stage of these cycles.

\section{A brief reference to the situation in 2008}

The comparison between 1997 and 2008 with regard to tree densities observed in mature farms older than 15 years illustrates the decline of cocoa-oil palm agroforestry in Côte d'Ivoire. Beside an increasing density of mature cocoa, and despite a huge variance, we see a decline of mature forest shade trees, which are progressively removed (table VIII). In 2008, it appeared a situation of "minimal shade" to "zero shade". The decline also includes coffee, which no longer interests farmers.

The most spectacular change concerns the wild oil palm population. While oil palm had literally invaded the cocoa farms in 1996, they had been kept at a relatively low density per hectare in 2008 (12 times less for the oil palm younger than 5 , and 4 times less for the oil palm of 5 and older). Why?

Table VII.

Ways palm trees were introduced on cocoa farms as described by migrant farmers.

No palm trees in the dense forest plots. Seeds were brought by birds (calaos) and/or rats and squirrels

Palm tree grew mostly by themselves, but we also sowed some (seed taken from wild palms or from farms owned by indigenous farmers)

The plot was a degraded fallow land where there were already plenty of oil palms growing

All the seeds came from one giant oil palm in the forest plot

Palm trees grew from grains left by our ancestors or the former owners

The 1983 fire spread into that yam field after which palm trees grew rapidly 


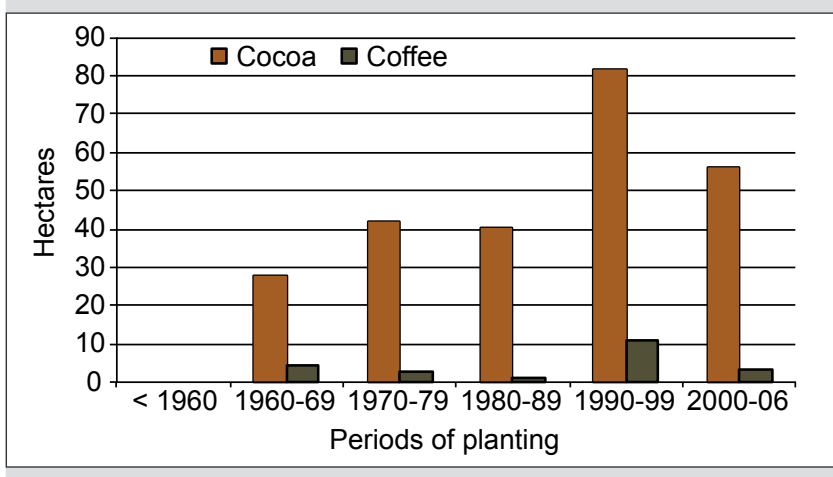

Figure 3.

Dates of planting of cocoa and coffee

in the region of Ouragahio in 2006.

\section{Investment by Burkinabè migrants}

In the 2000s, labour force and entrepreneurship brought by a new wave of Burkinabè immigrants prevented the abandonment of cocoa farms. The mid-late1990s were a period of active purchase of these abandoned coffee-cocoa farms by Burkinabè migrants from old autochthons and even Baoulé migrants, both in urgent need of cash. These Burkinabè migrants were progressively reconverting abandoned farms into cocoa plantations. To a lesser extent, as the economic crisis was hitting people in the cities, autochthons' sons and Baoulé migrant sons also came back to villages and participated in farm maintenance.

\section{Farmers' knowledge and generation change}

Farmers' knowledge, including that of the next generation, has also improved. This story in the mid-1990s helped them to notice the negative impact of excessive oil palm densities on cocoa tree health and yield. Farmers often refer to the negative environmental impacts of a too high density of young and old palm trees in the cocoa farms: competition for soil nutrients, difficulties to spray the farm if too many young oil palm, competition for light and lower cocoa production, squirrels' habitat, competition for water resources.

\section{Still more ageing cocoa farms in the late 2000s}

The centre-west was the receptacle of a first massive wave of migrants and planting in the 1970s. In 1996/97, this generation was hit by the ageing process of cocoa trees. But the 1980 s were the theatre of a still more powerful pace of investment in new planting (figure 3). The ageing problem and decline in cocoa yields came in the late 1980s. There are less palm trees per hectare but there are still more hectares of old cocoa, and finally still an abundant supply of palm wine.

\section{A declining palm wine / cocoa price ratio}

For these reasons quoted above, and also because palm wine has a limited lifespan for an healthy consumption, limiting the market to mostly local consumption, its selling price in villages has been remaining at a miserable 100 CFA franc per litre while the price of cocoa eventually increased after 2006. The price ratio of one kilogramme of cocoa and one litre of palm wine increased from 4 in 1996 to 6 in 2008 and 8 in 2010. The fact that the price of palm wine does not yet follow the recent trend of the cocoa price indicates that the oil palm tree stock is still relatively abundant.

\section{Conclusion}

This wild oil palm / cocoa agroforestry has clear limits. It was not a way to increase cocoa longevity, a service that shade trees in cocoa are often expected to provide. It was rather a half-natural half-man made way to compensate for cocoa mortality in ageing farms. In addition to some negative ecological services such as the presence of squirrels and snakes and the weedy nature of palm trees, the main limit was the marginal percentage that palm wine represented in cocoa farm monetary revenues that is further reduced by lost cocoa revenue if oil palms become too abundant. Except the Muslims people, cocoa farmers are fervent consumers as well as producers of palm wine. This domestic market is too narrow.

However, from an economic and social perspective, it should not be forgotten of the important self-consumption of palm wine and a non-negligible production of palm oil. Actually, the advantages of the "cocoa/wild oil palm agroforestry system" and the role of "Bangui" were numerous in a period of crisis: nutritional intake, emergency funding, insurance in case of (minor) family problems, potential complementary income during the lean months of cocoa, social cohesion, festivities, and last but not least, as an economic and institutional link between generations. In the absence of an active financial system that farmers can easily access, a tree farm can be considered as a bank portfolio and oil palm as free shares distributed every year to shareholders. As (cocoa) revenues were low, farmers had the option to sell some "oil palm shares" from their saving account in the field. This combination of cocoa and wild oil palm systems deserved the name of agroforestry, as an improved version (through revenue generation from palm wine during the fallow phase) of the "perennial" crop shifting cultivation. This sequence is a kind of relay cropping strategy based on the partially spontaneous growth of wild oil palm

Table VIII.

Mean tree population in mature cocoa farms older than 15 years in the Central-western region according to surveys performed in 1997 and 2008 with 56 and 57 observations, respectively.

\begin{tabular}{|c|c|c|c|c|c|c|c|c|c|}
\hline & Age of & & & & Number or $t$ & ees per hectare & & & \\
\hline & cocoa & Cocoa & Coffee & $\begin{array}{c}\text { Young } \\
\text { Forest trees }\end{array}$ & $\begin{array}{c}\text { Mature } \\
\text { Forest Trees }\end{array}$ & $\begin{array}{l}\text { 0il Palm } \\
\text { < } 5 \text { years }\end{array}$ & $\begin{array}{l}\text { Oil Palm } \\
>5 \text { years }\end{array}$ & Fruit trees & Plantain \\
\hline 1997 Average \pm St. dev. & $23.7 \pm 3.8$ & $960 \pm 469$ & $72 \pm 193$ & $5.5 \pm 19.0$ & $11 \pm 33$ & $348.4 \pm 338.4$ & $80.1 \pm 111.7$ & $9.5 \pm 33.5$ & $97 \pm 163$ \\
\hline 2008 Average \pm St. dev. & $23.4 \pm 4.7$ & $1352 \pm 384$ & $19 \pm 46$ & $3.5 \pm 8.6$ & $2.7 \pm 6.0$ & $27.9 \pm 26.8$ & $22.3 \pm 27.3$ & $15.5 \pm 24.2$ & $69 \pm 119$ \\
\hline Sign. (P value) & n.s. & 0.000 & 0.045 & n.s. & 0.063 & 0.000 & 0.000 & n.s. & n.s. \\
\hline
\end{tabular}




\section{Bibliographical references}

This story is interesting in terms of conjunction of "plantation cycles", family cycles and eventually "agroforestry cycles". In this West central region of Côte d'Ivoire, the "natural" build-up of abundant oil palm stock over years, previously evaluated in 1996/97, was mostly determined by cocoa ageing and farmer's neglect, itself the result of farmers' ageing and inheritance conflicts (especially among the autochthons, with an average abandonment of 2.8 years related to these inheritance problems), hampering maintenance, automatically triggering a growth of bush species in the humid tropics. The "unplanned" agroforestry system brought an equally unplanned resilience, ecologically and socially.

This story is also extremely interesting in terms of interactions of policies with agricultural systems and family life cycles. In 1994, policy makers who adopted a devaluation policy did not even think to its potential impact on demand of palm wine and certainly not its match with the abundant supply generated by ageing cocoa farms and farmers. Yet, these wild oil palm populations in old cocoa and coffee farms helped farmers cope with the economic impacts of the devaluation.

The informal value chain of palm wine may remain the best option for farmers and rural traders to get a significant share of its value. However, among potential measures that would go along a potential next devaluation, policy makers and agro companies could discuss with farmers how to better use this resource out of the cocoa farms. A too low price of "agroforestry products" are often the limit of agroforestry system in terms of "intensification". If the commodities are under-valued on local markets, the additional production of the agroforestry system cannot sufficiently contribute to increase revenues per hectare. This is here what prevents the cocoa/oil palm from passing the resilience stage to the intensification one.

By default or as a kind of counter example, this story is a plea for a kind of agroforestry and diversification that include high value commodities and downstream processing that can increase the added value of the commodity. The local palm-wine market proved to be too weak to generate an intensive exploitation of palm trees. Their potential is just kept in reserve, in case it becomes more profitable. In the 2010s, Ivorian cocoa farmers are increasingly opting for clonal rubber that brings regular revenues but they are still lacking trees such as oil palm that play the role of easily realisable saving.

As the pace of cocoa planting has slowdown in the 2000 s in many regions, the need to raise again the density of oil palm trees may come back. Other recommendations would be of course to work with smallholders on processing, possibly that of the "koutoukou" alcohol, preferably on a pasteurized palm wine in order to better deal with urban markets. A kind of certification of palm wine produced by wild oil palm, producing a lower volume but a better quality of wine, could be also an option but would imply a costly monitoring.
BASTERRECHEA T., PENOT E., RUF F., LE GRUSSE P., 2011. Diversification et durabilité : introduction des arbres à bois dans les cacaoyères. Le cas de Samreboi, au sud-ouest du Ghana. In : Penot E. (Éd.). Exploitations agricoles, stratégies paysannes et politiques publiques. Les apports du modèle Olympe. Versailles, Éditions Quæ, p. 77-95.

CHAMPAUD J., 1970. Mom (Cameroun) ou le refus de l'agriculture de plantation. Études rurales, 37/39: 299-311.

CHAUVEAU J.-P., 2006. How does an institution evolve? Land, politics, intergenerational relations and the institution of the tutorat amongst autochthons and immigrants (Gban region, Côte d'Ivoire). In: Kuba R., Lentz C. (Ed.). Land and the politics of belonging in West Africa. Boston, Brill, p. 213-240.

CHAUVEAU J.-P., COLIN J.-P., 2010. Customary transfers and land sales in Côte d'Ivoire. Revisiting the embeddedness issue. Africa, 80 (1): 81-103.

DUPRAZ P., MORISSON M., 2013. Place du cacaoyer et du cocotier dans les plantations familiales de la Malaisie péninsulaire. In : Ruf and Schroth (Ed.). Cultures pérennes tropicales. Enjeux économiques et écologiques de la diversification. Versailles, Éditions Quæ, p. 243-264.

FEINTRENIE L., SCHWARZE S., LEVANG P., 2010. Are local people conservationists? Analysis of transition dynamics from agroforests to monoculture plantations in Indonesia. Ecology and Society, 15 (4): 37.

LÉONARD E., OSWALD M., 1996. Une agriculture forestière sans forêt. Changements agro-écologiques et innovations paysannes en Côte d'Ivoire. Natures Sciences Sociétés, 4 (3) : 202-216.

RUF F., 1991. Les crises cacaoyères. La malédiction des âges d'or? Cahiers d'Études Africaines, 121-122 : 83-134.

RUF F., 1994. Le cacao : cycles, coûts, externalités. Quelle place pour le politique. In : Benoit-Cattin M., (Éd.). Économie des politiques agricoles dans les pays en développement, vol. 3. Éditions de la Revue Française d’Économie, Paris, p. 149-198.

RUF F., 1995. From the forest rent to the tree capital; basic laws of cocoa cycles. In : Ruf F., Siswoputanto, P. S. (Ed.). Cocoa Cycles. The Economics of Cocoa Supply. Cambridge, Woodhead Publishing, p. 1-53.

RUF F., DEHEUVELS O., SARPONG D., 2006. Intensification in cocoa cropping systems: is agroforestry a solution for sustainability? The case of Manso Amenfi, Western Region, Ghana. 15th International Conference on Cocoa Research, 1: 355-364.

SCHROTH G., KRAUS U., GASPAROTTO L., DUARTE AGUILAR J. A., VOHLAND K., 2000. Pests and diseases in agroforestry systems of the humid tropics. Agroforestry Systems, 50: 199-241. 